\title{
Private Maritime Security Contractors and Use of Lethal Force in Maritime Domain
}

\author{
Jasenko Marin, Mišo Mudrić, and Robert Mikac
}

\section{Introduction}

The following chapter analyzes the recently emerged phenomenon of the use of force at sea by private actors (private maritime security companies). The utilization of force in the maritime domain by private actors - a novelty in the modern common international experience ${ }^{1}$ - proved to be a considerable challenge to international law and good practice. After initial antagonism, the international community has gradually accepted the notion of utilizing private maritime security companies. Following the plight of individual coastal states (most notably, the United States (US)) and certain parts of the shipping industry, more and more nongovernmental actors became reliant on the private maritime security services within a short period of time, forcing the International Maritime Organization (IMO) to reassess its position with regard to the use of force at sea by private actors. ${ }^{2}$ This made it necessary to adjust the international approach as, up to that point, it was in principle prohibited for private actors to carry arms- the notable exception (recognized by the relevant international maritime law and law of the sea

\footnotetext{
${ }^{1}$ For a general background with regard to the standard private security industry regulation, see: Chesterman and Lehnardt (2007), Mikac (2013), Chapter III; Tonkin (2011), Percy (2006) and Jäger and Kümmel (2007).

${ }^{2}$ For more information, especially with regard to the soft-law bottom-up approach to the regulation of private maritime security companies, see: Mudrić (2015a), pp. 53-55.
}

J. Marin $(\bowtie) \bullet$ M. Mudrić

Department for Maritime and Transport Law, Faculty of Law, University of Zagreb, Zagreb,

Croatia

e-mail: jasenko.marin@pravo.hr; miso.mudric@pravo.hr

R. Mikac

Department of International Politics and Diplomacy, Faculty of Political Sciences, University

of Zagreb, Zagreb, Croatia

e-mail: robert.mikac@fpzg.hr 
conventions and relevant domestic law maritime codes and acts) allows the Masters of Vessels and First Officers to make use of personal firearms that have to be kept under lock and key at all times. The security of people and goods at sea-falling at the same time within the sphere of individual, national, and also common interests - thus became reinforced by an unprecedented enforcement methodology.

The present chapter particularly focuses on the issue of lethal force utilized by privately contracted armed security personnel (Contractors) ${ }^{3}$ as governed by the standard security services on board vessel contract form, the GUARDCONContract for the Employment of Security Guards on Vessels (GUARDCON). ${ }^{4}$ The contractual provisions, such as the example of GUARDCON, are often accompanied by the standards of conduct and separate rules on the use of force, developed either by an individual private maritime security company or by a professional body or association (usually consisting of private maritime security companies and/or other interested stakeholders). Several guidelines and recommendations, drafted particularly for the maritime domain (i.e., the IMO Guidance, the Baltic and International Maritime Council (BIMCO) Guidance, the 100 Series Rules, the IAMSP Rules on Use of Force, the ISO/PAS 28007:2012, and the ASIS/ANSI PSC. 4) will be analyzed and compared in order to assess the extent to which, inter alia, the issue of the use of force is harmonized on a global level. Due to the fact that none of these documents are mandatory and legally binding, they are necessarily accompanied and intertwined with domestic regulation or nonbinding recommendations, as well as general domestic criminal and civil laws, especially in connection to the issue of self-defense. A number of jurisdictions will, therefore, be analyzed in order to examine the noted interconnection.

\section{The Shifting Nature of Maritime Security}

The core actors in the maritime-related privatization of violence encompass the full spectrum of shipping-related stakeholders, including nongovernmental actors concerned with the issue of human rights at sea-a separate drive that reviews the phenomenon of the use of force at sea by private actors as a possible insecurity factor, leading to an increased level of violence and increased insecurity of people and goods at sea. Thus, the conjunction of individual, national, and common interests is interrupted by a conflict of interest within its core-in order to achieve better security, one forgoes principles that have ensured security thus far. This dilemma is ever so problematic, especially when considering that the primary goals of any sound ocean security governance are to promote peaceful use of the seas and oceans (as stipulated by the 1982 Convention on the Law of the Sea and other

\footnotetext{
${ }^{3}$ Often used abbreviation: PCASP.

${ }^{4}$ Baltic and International Maritime Council, see: BIMCO (2012a). For a legal analysis of GUARDCON, see: Mudrić (2015a, b).
} 
related international instruments). It, therefore, continues to be true that the privatimilitarization of sea in the name of peace remains a dubious concept, despite the argument that the utilization of violence by private actors only serves to promote the noted principle of peace.

The initial conflict of interest has slowed down the bottom-up lawmaking process. This is especially true for the period when the majority of states have continued to adhere to the state's monopoly on violence principle at sea, ${ }^{5}$ despite the fact that this principle has long been breached with regard to the activities of private military and security companies on land, including such companies working directly for government institutions in and outside of conflict (war) zones. But when the shipping and insurance driving forces ushered in the private contractors in the maritime domain, the states, already accustomed to the utilization of private security industry on land, soon adjusted to the emerging subbranch of the global private security industry. Initially-keeping in mind that the predominant maritime-related interest of the international community as a whole continues to be the security of people and goods at sea - the introduction of firearms held by private entities into that realm was considered as a violation of the common interest (leading to the possible spread of and an increase in violence). This perception has, however, gradually transformed into a compromise solution whereby the security services are to be offered by professional entities trained and properly equipped to utilize violent means when no other means are available to thwart the realization of danger to people and goods at sea in accordance with the best industry practice, such as the example of the Montreux Document (not relevant for the maritime sector). ${ }^{6}$

The role of the state was, therefore, diminished to a certain extent, partially due to the private contractual nature of private maritime security services (as opposed to such instances when states contract private actors to do their bidding), even though states persist in their determination to remain the watchful dog through carefully drafted legislation. The impact of this effort is, however, dubious due to the practical difficulties of control and supervision enforcement. At the same time, the role of the private sector in the protection of seas and oceans continues to increase-the scope of utilization echoing beyond any precedent.

Nevertheless, the compromise solution does not disentangle the continuous dilemma as to whether the introduction of private actors' right to utilize force at sea equals a step closer to or a step further away from the general security of people and goods at sea, posing a serious challenge to the law of the sea and ocean security governance. The latter is especially true when considering the appearance of private armed flotillas that today offer security services to individual vessels while tomorrow they may potentially be utilized for a broader (private) purpose, exempt from

\footnotetext{
${ }^{5}$ For more information, see: Petrig and Gei $\beta$ (2011), Tondini (2012), Williams (2014), Coito (2013) Berube and Cullen (2012), Andreone et al. (2013), Kraska (2011) and Mejia et al. (2013). ${ }^{6}$ For more information on the Montreux Document, see: International Committee of the Red Cross (2009) and Buckland and Burdzy (2013).
} 
any form of organized, institutional control. In the context of the emerging field of Maritime Security Studies, ${ }^{7}$ private armed flotillas may alternatively function under a hidden organized, institutional control, as one means of hybrid maritime warfare, somewhat similar to when the Letter of Marque granted certain formal authority to the private actors of the past.

At the same time, when states ratify international instruments, they are granted certain rights but are, at the same time, bound to accept certain obligations as well. The security of people and goods at sea is a general obligation present in various international conventions, including the 1982 Convention on the Law of the Sea. The emergence of maritime crimes and piracy poses such security threats that must be tackled swiftly and without delay, and the lack of proper domestic tools necessary to combat such occurrences is a poor excuse for nonperformance. An analogy with the private salvage industry serves to demonstrate that the need for such an industry is brought about by the inability of the majority of coastal states to train, equip, and maintain a domestic salvage capacity, thus being heavily reliant on the private salvage industry to meet their needs and fulfill their obligations.

It remains to be seen whether the utilization of private actors in the context of providing maritime security services may potentially become a standard mechanism in case a certain set of conditions is met, thus entangling the private sector into the regular network mechanism of domestic maritime security. It should be noted that the sanctioning of private actors' right to utilize force was just one aspect of the international response to the scourge of piracy, and it took a while to formulate, following a careful evaluation. In the context of the recent Mediterranean crisis and the increased human trafficking by sea, whereas certain stakeholders argue for the employment of private actors in, among other things, combating organized crime, state navies-European Union in particular-have long initiated joint efforts to fight the smugglers. The effort has been reinforced with the relevant United Nations Security Council's resolutions, enabling further steps to be undertaken, much similar to what was witnessed in Somalia several years ago (which has, among other factors, enabled the overt in-land combat activities as conducted by the Joint Special Operations Command and other militaries that have by far most contributed to the elimination of the pirate outposts in the region). During the height of the piracy threat, similar state navies' activities were initiated in the Somalian waters and the Gulf of Aden (still active today), providing safe passage to the vessels that can afford to wait, and patrolling over the High Risk Area, representing predominantly moral support to all the endangered seamen. At the same time, the newly developed piracy tribunals were kept busy in prosecuting captured piratescourtesy of the previously mentioned navies-whereas a small number of cases appearing before the regional coastal states' courts have tackled the issue of private maritime security companies offering their services without any proper documentation or licenses. Quite recently, one case has appeared before the International

\footnotetext{
${ }^{7}$ For more general information and background, see: Bueger (2015), pp. 159-164, and Kraska and Pedrozo (2013).
} 
Tribunal for the Law of the Sea that deals with the issue of alleged unlawful use of force at sea (Enrica Lexie).

\section{Use of Force, Regulation, and Consequences: General Overview}

On 22 October 2014, the Washington jury found four former Blackwater (US private military and security company) private security guards guilty of several charges-murder in the first degree, manslaughter, and attempted manslaughter. This is the result of a 7-year investigation and proceedings following the all-out shoot-out at Nisour Square, Baghdad, Iraq, on 16 September 2007. ${ }^{8}$ The first instance decision (pending appeal), based on the jury's verdict, represents a rare example where the employees of a private military and security company have been found accountable and responsible for conduct exhibited during the performance of a contracted security service that has caused bodily harm and death to innocent bystanders. It also represents a rare occasion where the issue of the use of force by private actors has been legally scrutinized.

On 15 February 2012, two Italian marines, providing government-authorized Vessel Protection Detail (VPD) ${ }^{9}$ service to the Italian tanker Enrica Lexie, allegedly shot and killed two Indian fishermen. The proceedings are still under way. ${ }^{10}$

The former is an example of (questionably) excessive use of force when providing private military and security service on land and the latter of (questionably) excessive use of force when providing (private) maritime security services. Both examples represent what is often referred to as a "hot potato" or an "elephant in the room"- an issue very difficult to tackle, assess, and regulate. The law, in general, allows the use of force (the right of an individual to use force as a defensive measure), including the lethal kind, only when absolutely necessary and only when it serves to prevent equal or greater harm. This is generally accepted as lawful use of force. What amounts to excessive use of force or unlawful use of force is something difficult to ascertain through clear regulation and very much depends on the circumstances of each particular case. Any conclusion reached by a tribunal thus easily falls into the arena of criticism.

Incidents at sea with deadly consequences are being reported at an increasing rate. Beginning with as early as March 2010, ${ }^{11}$ unfortunate events involving the death of innocent fishermen are becoming a harsh reality, ${ }^{12}$ placing a growing shadow on the provision of private maritime security services in general.

\footnotetext{
${ }^{8}$ See: Los Angeles Times, October 22, 2014.

${ }^{9}$ For more general information on VPDs, see: Guilfoyle (2013), p. 221 et seq.

${ }^{10}$ See: The Hindu, December 16, 2014.

${ }^{11}$ See: Symmons (2012), 36- the "MZ Alinezaan" case.

${ }^{12}$ See, for example: Katz (2012).
} 
Simultaneously, a growing number of reports indicate possible excessive behavior of individual armed security guards. ${ }^{13}$

With regard to the maritime domain, IMO and the private maritime security services industry have produced a number of legally nonbinding rules with the purpose of providing guidance to states, private maritime security service providers, and clients with regard to, inter alia, the use of (lethal) force. ${ }^{14}$ An increasing number of states have also adopted guidelines and/or ordinances with regard to the provision of private maritime security services. A number of such legal documents will be examined in this chapter in order to ascertain the extent to which the issue of the use of force has been regulated and/or considered. Only a small number of available documents are legally binding in nature - most are offered on a voluntary basis, with the private maritime security industry, which claims to be a professional industry, being under increased pressure to willingly incorporate such recommendations into their standard operation procedures. The courts will have a final say, but the fact that only a fraction of reported incidents concerning the provision of private security services on land and none in the maritime domain have reached the courts speaks of the sensitivity and difficulty of the issue at hand.

Several attempts were made in the past to produce an international convention regulating the activity of private military and security companies in general, ${ }^{15}$ but no such project came to life, likely due to the fact that the use of private security providers, although present throughout the ages (especially in the few recent decades), ${ }^{16}$ contradicts the fundamental monopoly of the state over the use of force and, as such, creates ambiguous feelings towards a formal recognition of their indispensable status in the modern world. However, one should not neglect the fact that, very often, states directly contract private military and security companies' services, thus effectively authorizing such companies to utilize violent measures (derived from the state's monopoly on violence) when necessary and appropriate. In other words, depending on the nature of a particular operation, an activity performed by the engaged private actor may constitute an activity so inherent to the notion of state sovereignty and state performance that any formal line of differentiation - of where the state's functions end and private actor's separate operations begin-is easily blurred in practice. Any proper international instrument that would regulate the conduct of private security companies would have to take that into consideration and provide for an equal level of measures in case of a breach of an obligation, against both the private actors and government institutions that employed them, and possibly other relevant states (in line with the Montreux principles). This is perhaps another reason for ambiguity with regard to the existence of such an instrument, which requires further consideration.

\footnotetext{
${ }^{13}$ See: Dutton (2013), p. 111 et seq.- -the "Avocet" case.

${ }^{14}$ See generally: Mudrić (2011), p. 165.

${ }^{15}$ For more general information, with the focus on maritime domain, see: Dutton (2013), p. 140. Especially see: Scheimer (2009).

${ }^{16}$ For more information, see: Mikac (2013), Chapter II.
} 


\subsection{Prelude to Precedent}

In the much-discussed and still ongoing case Enrica Lexie, the use of force utilized by a six-strong Italian military protection team led to the undesired consequence of two Indian fishermen being shot dead.

Although most of the facts are continuously being disputed by the involved parties, ${ }^{17}$ awaiting the final court determination, the early sources indicated that (a) the incident occurred during the day; (b) the fishing trawler had at one point allegedly maneuvered toward the tanker (in accordance with some accounts, this consisted of a sharp move towards the tanker, in order to pass by the stern-difficult to be confirmed due to the fact that seven out of nine fishermen present on the trawler were asleep at the time of the incident, and the two in charge of navigation were killed); (c) the vessel made no attempt to avoid the approach; (d) the Team Leader failed to consult the Master of Vessel or any of the crew with regard to the steps to be taken (in accordance with the Master's and First Officer's testimony ${ }^{18}$ ); (e) warning shots fired (the Italian marines claim that they utilized warning light signals prior to the shooting - an action with a dubious effect during the day) resulted in lethal consequences, thus failing to fulfill their purpose; (f) the fishermen were not armed, nor did they exhibit any hostile intentions (the inspection of the tanker failed to produce any evidence of the tanker being fired upon, which was argued by the Italian marines); (g) the tanker failed to immediately report the incident to the proper authorities and proceeded with its voyage; and (h) the Indian Coastal Police alerted the Indian Coastal Guard, who contacted the tanker, which only then altered its course and steered back to the port of Kochi. ${ }^{19}$

The questions pending before the Indian Supreme Court ${ }^{20}$ are whether the Italian marines acted in accordance with the Rules of Engagement (it is relevant to note that the service provided by the Italian marines is derived from the state's monopoly over the use of force ${ }^{21}$ ) and whether their actions entail criminal and/or civil responsibility and liability. The decision to be reached by the Indian court will make a significant impact on the provision of private maritime security services and the issue of rules on the use of force as it will provide a much-awaited court determination with regard to the use of force in general and the use of lethal force in particular.

\footnotetext{
${ }^{17}$ For more information on the Indian position and the decisions reached by the Kerala High Court, see: Gandhi (2013), pp. 3-5. See, however, the formal position of the parties as submitted to the International Tribunal for the Law of the Sea portal, The "Enrica Lexie" Incident (Italy v. India), Case No. 24, available at: https://www.itlos.org/en/cases/list-of-cases/case-no-24/.

${ }^{18}$ See, for example: Reuters, 10 June 2013.

${ }^{19}$ See: Eboli and Pierini (2012), p. 4.

${ }^{20}$ Subject to the International Tribunal for the Law of the Sea Order 24 of August 2015, whereby both parties are ordered to suspend all court proceedings which might produce a negative effect with regard to the dispute submitted to the arbitral tribunal, see: International Tribunal for the Law of the Sea (2015).

${ }^{21}$ For more information, see: Petrig (2013), pp. 669-670.
} 


\subsection{Use of Force}

\subsubsection{Right to Self-Defense}

In accordance with the generally established principle of self-defense, a person causing damage (actor) has a legally valid defense when utilizing reasonable measures to protect himself or a third person, provided that the injured party has endangered the protected interests. ${ }^{22}$ The actor must demonstrate the necessity of the defensive measures and ensure that the defensive measures are proportionate to the perceived threat. ${ }^{23}$ If that is the case, it will be deemed that any damage so caused is a legally relevant damage and that it is for the sole accountability and responsibility of the other (injured) person endangering the protected interests to suffer the consequences (liability) of the legally relevant damage. ${ }^{24}$

In the context of the current examination, a good example is the incident that occurred on 15 October 2014 in the Gulf of Aden, where a motor yacht reported an approach by a skiff with four people on board, up to a distance of 500 meters, followed by warning shots fired by the Contractors after the weapons and ladders were sighted. $^{25}$ The skiff followed for a while but decided not to pursue. In another good example that occurred in the Gulf of Aden, three pirate skiffs made two attempts to approach the vessel. ${ }^{26}$ The first approach was deterred through the use of nonviolent evasion measures, whereas during the second approach it was necessary to utilize indirect force (first, a so-called parachute flare-on three separate occasions, followed by the second measure in the form of indirect warning shots) in order to persuade the skiffs to move away. Such examples represent a model scenario on how force is to be used, under what circumstances, and up to what extent of severity.

The actor may, however, be held liable (for damage) if the defensive measures are unreasonably excessive or disproportional to the actual threat (excessive selfdefense) or if there was no actual threat (putative self-defense), as examined in further text.

\footnotetext{
${ }^{22}$ Compare: von Bar and Clive (2010), VI. - 5:202, 3665.

${ }^{23}$ Compare: The M/V "SAIGA" (No. 2) Case (Saint Vincent and the Grenadines v. Guinea), International Tribunal for the Law of Sea, ITLOS Rep. 10, $\S 155$. For more information on the case, see: International Tribunal for the Law of Sea portal, available at: https://www.itlos.org/ cases/list-of-cases/case-no-2/case-no-2-merits/.

${ }^{24}$ Von Bar and Clive (2010), VI. - 5:202: Self-defense, benevolent intervention, and necessity.

${ }^{25}$ Maritime Security Centre-Horn of Africa (MSCHOA).

${ }^{26}$ Aburgus Risk Management, October 2014c.
} 


\subsubsection{Relevant Maritime-Related National Legislation and Guidelines}

A growing number of jurisdictions have enacted laws, ordinances, and recommendations with respect to the provision of private maritime security services. Such legal documents usually contain several important considerations with regard to the right to use force and the limitations of such use.

The US Port Security Advisory (3-09) Guidance on Self-Defense or Defense of Others by U.S. Flagged Commercial Vessels Operating in High Risk Waters (PSA), by definition, includes the use of deadly force within the scope of the right to selfdefense (Rule 2(a)), ${ }^{27}$ whereby the Master of Vessels retains final authority with respect to the decision to utilize force (Rule 3(a)). ${ }^{28}$ The PSA defines imminent danger as a situation when " . . an attacker manifests apparent intent to cause great bodily harm or death..." to others, provided that the attacker possesses adequate means (i.e., weapons, climbing gear, etc.) and acts when the opportunity so permits. $^{29}$

The United Kingdom's (UK's) Interim Guidance to UK Flagged Shipping on the Use of Armed Guards to Defend against the Threat of Piracy in Exceptional Circumstances, ${ }^{30}$ recognizing the Master's overall authority (Rule 5.1), sets a number of rules to be adhered to when considering the use of deadly force. The use of force must be proportionate and reasonable (Rules 5.6, 8.9, and 8.10), kept to the minimum necessary level, and can only be leveled up at a gradual basis (Rule 8.3). The Interim Guidance allows for preemptive strikes provided that an attack is imminent (Rule 8.12), keeping in mind that a mere sighting of a possible threat is not to be considered as an imminent danger (Rule 8.13).

A similar provision is available in the Croatian Ordinance on the requirements for legal persons providing the services of boarding armed escort on Croatianflagged vessels ${ }^{31}$ whereby the Team Leader must sign a statement recognizing the Master's final authority over the use of firearms that are to be utilized at a minimum possible capacity sufficient to thwart an attack (Article 9(2)), subject to the general Croatian criminal law provisions.

\footnotetext{
${ }^{27}$ U.S. Department of Homeland Security, United States Coast Guard, Port Security Advisory (3-09), Guidance on Self-Defense or Defense of Others by U.S. Flagged Commercial Vessels Operating in High Risk Waters. For a critical assessment of Port Security Advisory, see: Patrick (2014), pp. 350-355.

${ }^{28}$ PSA 3(a)., subject to: Title 33-Navigation and Navigable Waters, Chapter 6-General Duties of Ship Officers and Owners after Collision or other Accidents, 33 U.S.C. § 383-Resistance of pirates by merchant vessels.

${ }^{29}$ PSA, ibid.

${ }^{30} \mathrm{UK}$ Department for Transport, Interim Guidance to UK Flagged Shipping on the Use of Armed Guards to Defend Against the Threat of Piracy in Exceptional Circumstances, Version 1.2, Updated May 2013.

${ }^{31}$ Pravilnik o uvjetima koje moraju ispunjavati pravne osobe koje pružaju usluge ukrcaja osoba za naoružanu pratnju na brodove hrvatske državne pripadnosti, Narodne novine (Official Gazette), broj (No.) 123/12.
} 
The requirement of adherence to the general criminal law provisions on selfdefense is restated throughout the Italian Regulation on the employment of contractors on board Italian-flagged ships sailing in international waters under piracy risk,${ }^{32}$ whereby lawful and proportionate use of force is limited to self-defense.

The Indian Guidelines on Deployment of Armed Security Guards on Merchant Ships ${ }^{33}$ refer to the necessity of taking all reasonable steps in order to avoid the use of force that may only be utilized if necessary and in a proportionate manner (Rule 6.9(2)), and only provided that there is an imminent danger (Rule 6.9(3)). ${ }^{34}$

The Norwegian Provisional Guidelines-Use of Armed Guards on Board Norwegian Ships ${ }^{35}$ allow the use of force only when the threat is "direct, immediate, significant and otherwise unavoidable" and only to the extent that the utilization of force is "necessary, justifiable and proportionate" (Rule 10(2)). Irrespective of the fact that the Master of Vessel retains final authority, the responsibility for the decision to use force resides on the individual making such decision (Rule 10(7)). The Norwegian Guidelines mention a very specific determination of a distance of 2000 meters as viable to assess an actual threat (Rule 10(3)). Another relevant Norwegian-originated set of guidelines is available under the auspices of the Norwegian Shipowners' Mutual War Risks Insurance Association-The Guidance on the Selection of Private Security Companies..$^{36}$ The Guidance stipulates that when a threat has been reasonably identified and classified as a hostile intent or a hostile act (Team Leader and Master of Vessel deciding in conjunction), the Team Leader is to assume tactical command, with the possibility of using firearms as a last resort, leading towards, with a gradual progression, the use of deadly force as an ultimate resort (Rule 2).

\subsubsection{Excessive Self-Defense and Putative Self-Defense}

Determination of excessive self-defense is applicable for such occurrences where the measures used to thwart the attack are excessive when compared with the level of danger threatened. ${ }^{37}$ Putative self-defense denotes a situation when a measure of self-defense is utilized under the impression that there is an attack whereas, in reality, no attack is taking place. ${ }^{38}$

The Nisour Square incident provides a perspective for consideration. In response to the call from the Blackwater protection detail providing personal escort and

\footnotetext{
${ }^{32}$ Regulation on the employment of contractors on board Italian flagged ships sailing in international waters under piracy risk, 29th March 2013, Italian Official Gazette.

${ }^{33}$ Indian Ministry of Shipping (2011).

${ }^{34}$ See: Darshan Singh v. State of Punjab \& another, Criminal Appeal No. 1057 of 2002.

${ }^{35}$ Norwegian Mar. Directorate (2011).

${ }^{36}$ Den Norske Krigsforsikring for Skib—Gjensidig Forening, 2011.

${ }^{37}$ Von Bar and Clive (2010), VI. - 5:202, 3667.

${ }^{38} \mathrm{Id}$.
} 
protection to the USAID director-who was under attack - and upon request from the US State Department's regional security officer, ${ }^{39}$ the second Blackwater team left the Green Zone in an attempt to provide support and security on the route to be taken by the first team in order to reach the safety of Green Zone. The second detail reasoned that Nisour Square would make a good place for staging an ambush to the advancing first team. What follows has been heavily disputed in the proceedings and media coverage. ${ }^{40}$

At one point, a Kia motor vehicle had entered the Nisour Square's motorcade circle. The Blackwater team, as alleged by the defendants, ${ }^{41}$ made several attempts to signal the vehicle to stop in its tracks. As the vehicle was unresponsive and continued moving towards the armored column, and due to the fact that the Blackwater team, as well as any other security force in the theater of operations, was aware of the danger that such a vehicle could easily represent, the Blackwater team and the local police officers decided to stop the car, first by hand gestures and vocal commands and, after the vehicle remained unresponsive, by the use of force. The force was direct and mortal. What followed was complete chaos, resulting in many dead and wounded. ${ }^{42}$

The Blackwater company was operating at the time in accordance with its own rules of engagement but was additionally bound, by the virtue of Worldwide Personal Protective Service contract, ${ }^{43}$ by the US Embassy's Escalation of Force policy ${ }^{44}$ that requires a gradual and proportional use of force, taking into consideration that deadly force may have to be utilized immediately, depending on the circumstances. The Contractors further claimed that soon after the vehicle was repeatedly shot at, they came under enemy fire, and that they continued to act in self-defense. ${ }^{45}$ One could easily imagine that, being in the theater of operations such as the Baghdad, a better safe than sorry policy is a policy often utilized by all engaged forces, armed or otherwise. In this sense, excessive or putative self-defense is just one step away from becoming a victim, making it extremely difficult to tell the difference, let alone devise a set of rules defining any points of differentiation in advance.

It has often been reported that, especially in the High Risk Areas, fishermen sometimes carry weapons to protect themselves from potential pirate attacks. ${ }^{46} \mathrm{~A}$ mere sighting of weapons on board may not constitute a sufficient reason for immediate use of lethal force, unless the Contractors have a strong reason to believe

\footnotetext{
${ }^{39}$ As noted by Erik Prince, see: Prince (2013), Chapter 13.

${ }^{40}$ See: United States v. Slough, Criminal No. 2008-0360 (D.C. 2014), District Court, District of Columbia, Filed: May 23rd, 2014.

${ }^{41}$ See: Prince (2013), Chapter 13.

${ }^{42}$ See: Tarzwell (2009), pp. 181-183.

${ }^{43}$ For more information, see: Cheadle (2009), p. 689 et seq.

${ }^{44}$ See: U.S. Department of State (2006). Also see: U.S. Department of State (2009).

${ }^{45}$ See: Prince (2013), Chapter 13.

${ }^{46}$ See: Symmons (2012), p. 29. Also see: Murdoch (2011), p. 40.
} 
that the threat is imminent or present. At the same time, practical experience has shown that assailants are capable of concealing weapons and striking when unexpected, placing security guards or armed forces in a difficult position of telling the difference between an approaching vessel with a hidden agenda (simply acting as a fisherman) and an innocent passer-by (an actual fisherman). ${ }^{47}$ In addition, should they opt for the use of force, the question remains as to which rules they are to base their decision on whether the use of force is in order. ${ }^{48}$

\subsubsection{Assessment of Reasonable Conduct}

In order to understand how the utilization of self-defense in the maritime domain is determined and understood by the courts, it is necessary to point to several comparative examples of self-defense regulation applicable to all self-defense manifestations, including ones in the maritime domain. Various domestic law regulations and case law, both with regard to criminal and civil laws, in principle, presuppose similar elements and standards necessary for establishing the right to claim the self-defense exemption from or exclusion of liability. However, several important differences in the evaluation of excessive and putative self-defense conduct are to be noted.

French law and Belgian law require an objective assessment based on the conduct of a reasonable person or a reasonable professional under the same or similar circumstances. ${ }^{49}$ English and Welsh case law recognizes the principle of proportionality in comparing the act of self-defense with the act of attack but at the same time acknowledges the extreme circumstances where the balance of proportionality may be difficult to assess by the actor, stipulating the doctrine of reasonable vs. unreasonable mistakes. ${ }^{50}$ In accordance with Spanish law, in order to claim the self-defense exception, the actor must prove the existence of an unlawful and unprovoked attack where necessary and proportionate force was utilized in order to thwart that attack. ${ }^{51}$ Italian law follows the same principles but stipulates that in case of putative self-defense, it is likely that the principle of contributory negligence will be employed. ${ }^{52}$ Portuguese law further stipulates that in case of excessive self-defense applied out of fear, the actions will have been justified, ${ }^{53}$ leaving

\footnotetext{
${ }^{47}$ A good example being the attack on the USS Cole in 2000. For more information, see: Mikac (2013), p. 119.

${ }^{48}$ For more practical examples and general consideration, see: Neri (2012), p. 83.

${ }^{49}$ Compare: von Bar and Clive (2010), VI. - 5:202, 3669.

${ }^{50}$ Compare: Murphy and Witting (2012), pp. 334-335. Also see: Cross v. Kirkby (2000) Times, 5th April (CA) - where it was deemed relevant what was the defendant's genuine apprehension of the circumstances, and whether the critical moment increased the defendant's anguish. Also see: Palmer v. R [1971] AC 814.

${ }^{51}$ Compare: von Bar and Clive (2010), VI. - 5:202, at 3669-3670.

${ }^{52}$ Compare: ibid., at 3670.

${ }^{53}$ Compare: ibid., at 3672.
} 
no possibility for the actor's liability. Contrary to all the above, Bulgarian law does not provide any grounds for exclusion from civil liability, even if excessive selfdefense was applied due to fear or fright. ${ }^{54}$ German law, inter alia, requires the attack to be unlawful and imminent, ${ }^{55}$ with an additional rule stipulating that a professional person must be reasonably prepared for such circumstances and ready to use proportional force, ${ }^{56}$ whereas Dutch law, inter alia, requires the attack to be present. $^{57}$

\subsection{Standards, Guidelines, and Recommendations}

Parallel to IMO's publication of guidelines with regard to the provision of private maritime security services, a number of interested stakeholders, particularly on the side of shipping and related industries, have endeavored to issue similar guidance and recommendations, either to enhance the security of people and goods in relation to the provision of security services or to increase the popularity of such services. The emerging soft law, forged in the dwellings of corporate interests, soon began to develop into hard law-the so-called bottom-up law-making-with an increasing number of coastal and shipping states enacting laws and ordinances with regard to the provision of private maritime security services on board vessels flying their flags.

\subsubsection{IMO Interim Guidance}

In 2012, IMO issued the Interim Guidance to private maritime security companies providing contracted armed security personnel on board ships in the High Risk Area ${ }^{58}$ With regard to the use of force, recognizing the Master's overall authority (Clause 5.6(1)), the Guidance stipulates (Clause 5.15(2)) that it is necessary to undertake all reasonable steps in order to avoid the use of force, but should the use of force be deemed necessary, it should be conducted in a gradual manner, applying only such measures that are necessary and reasonable in the given circumstances (Clause 5.15(3)). ${ }^{59}$

\footnotetext{
${ }^{54}$ Compare: ibid., at 3671 .

${ }^{55}$ Compare: ibid., at 3671.

${ }^{56}$ Compare: ibid., at 3668 .

${ }^{57}$ Compare: ibid., at 3673.

${ }^{58}$ IMO (2012a).

${ }^{59}$ The noted recommendations are, in essence, repeated in the: IMO (2012b).
} 


\subsubsection{BIMCO Guidance and GUARDCON}

The BIMCO issued the Guidance on Rules for the Use of Force (RUF) by Privately Contracted Armed Security Personnel (PCASP) in Defence of a Merchant Vessel (MV) (BIMCO Guidance). ${ }^{60}$ The BIMCO Guidance should be read in conjunction with GUARDCON provisions relevant for the relationship between the Master of Vessel and Team Leader (Clause 5 BIMCO Guidance).

In accordance with Clause 8(b) GUARDCON, when under an "actual, perceived or threatened act of piracy," the Contractors' Team Leader has the right to invoke the Rules for the Use of Force, and the responsibility for and potential liability arising out of the discharge of weapons resides with the Contractors. Whereas, in accordance with Clause 8(d) GUARDCON, the Master of Vessel can order a ceasefire, each Contractor retains the right of self-defense (the use of lethal force included). This right is based on the Contractors' main duty (Clause 3 (b) GUARDCON) to provide protection and defense of the vessel ("using all reasonable skill and care"-Clause 6(a)), in accordance to which the Contractors do not guarantee the safety of Vessel (Clause 9) but, instead, promise to act to the best of their abilities.

In accordance with Clause 3(d), Clause 4(c) and Clause 4(d) BIMCO Guidance, the use of (lethal) force should be utilized only when essential and strictly necessary, ensuring that the measures undertaken are proportional and appropriate to the circumstances, and utilized at a minimum necessary level. Clause 4(f) BIMCO Guidance stipulates that all reasonable steps should be taken to avoid the use of lethal force. Furthermore, Clause 7 BIMCO Guidance defines the scope of graduated and proportional defense, requiring (Clause 7(a)(iii)) the use of nonviolent means first (except when circumstances necessitate immediate use of force)-such as the show of weapons-followed by (Clause 7(f)) a discharge of weapons in a graduated flow (warning shots, disabling fire, and, finally, deliberate direct fire). Clause 7(g) BIMCO Guidance requires certain exemplary conditions to be met before being allowed to use lethal force, such as the fact that the attack is ongoing despite the show of weapons and warning shots, with a clear and visible intention on behalf of the attacker to board the vessel, at the same time demonstrating the use of weapons.

\subsubsection{The 100 Series Rules ${ }^{\mathrm{TM}}$}

Another legally nonbinding set of rules with regard to the use of force, enjoying support from many relevant stakeholders, is the 100 Series Rules: An International Model Set of Maritime Rules for the Use of Force (RUF) (100 Series Rules). ${ }^{61}$ The

\footnotetext{
${ }^{60}$ BIMCO (2012b).

${ }^{61}$ Globus Intelligence Ltd (2013).
} 
100 Series Rules follows (Rule 100) the GUARDCON stipulation with regard to the relationship between the Master of Vessel and Team Leader.

The 100 Series Rules stipulate (Clause 17) that force should be used when necessary and/or reasonably required as a deterrent when an imminent threat to life is present and commensurate to the threat posed. Rule 101 stipulates the use of nonviolent means when there is a reasonable belief that a potential attack is due. Rule 102 stipulates the use of, inter alia, warning shots to thwart the attack. Finally, Rule 103 stipulates the right to use lethal force in case of an imminent attack, which is defined as a manifest, instant, and overwhelming occurrence.

The GUARDCON, BIMCO Guidance, and 100 Series Rules are interlinked with the ISO/PAS 28007:2012 Ships and marine technology_Guidelines for Private Maritime Security Companies (PMSC) providing privately contracted armed security personnel (PCASP) on board ships (and pro forma contract) ${ }^{62}$ (ISO/PAS 28007:2012) due to the fact that the organizations publishing or supporting the noted documents constitute the same or similar stakeholders, and often relate to each other. In addition, the "pro forma contract" mentioned in the title of ISO/PAS 28007:2012 - the quality standard with regard to the conduct of private maritime security companies - refers directly to the GUARDCON.

\subsubsection{IAMSP-2011-01-UOF-001 v2.0}

The International Association of Maritime Security Professionals (IAMSP) has issued the Use of Force, IAMSP-2011-01-UOF-001 v2.0 (IAMSP Rules). ${ }^{63}$ The IAMSP Rules are aligned with the Quality Assurance and Security Management for Private Security Companies Operating at Sea-Guidance ANSI/ASIS PSC. 4 $2013,{ }^{64}$ the quality standard that sets similar but more detailed provisions with regard to the conduct of private maritime security companies, when compared to the ISO/PAS 28007:2012. ${ }^{65}$

The IAMSP Rules place an emphasis on risk assessment (Appendix E IAMSP Rules), stipulating (Clause 63 IAMSP Rules) that the choice of use of force depends on the feasibility study. Clause 64 IAMSP Rules further stipulates that the use of force depends on the nature of attack, the potential for escalation, the attacker's intention, and other possibilities (such as the evasion of attack by other means). Clause 66 IAMSP Rules enhances the previous stipulation by requiring the Contractors to ensure due care and undertake all reasonable steps prior to the utilization of lethal force. Clause 68 IAMSP Rules stipulates that the final choice of whether to use lethal force is subject to the reasonability test, in accordance to which the escalation of force must equal the perceived threat in order for the use of lethal force

\footnotetext{
${ }^{62}$ International Organization for Standardization (2012).

${ }^{63}$ International Association of Maritime Security Professionals (2011).

${ }^{64}$ American National Standards Institute, Inc. ASIS International (2013).

${ }^{65}$ For more information on, see: Mudrić (2015b), pp. 61-62.
} 
to be allowed. The responsibility arising out of the use of lethal force (Clause 93 IAMSP Rules) resides on the person who, in accordance with the ship's log, authorized the use of lethal force. The IAMSP Rules provide a detailed reference with regard to the chain events leading to the use of lethal force (Appendix B IAMSP Rules). In order to establish the right to use lethal force, the Contractors must demonstrate, if possible, the following elements/steps: (a) suspicious vessel, (b) sighting of weapons and boarding equipment, (c) potential use of nonviolent means, ${ }^{66}$ (d) warning shots, and (e) direct fire. With regard to the escalation of force, the IAMSP Rules detail (Appendix C IAMSP Rules) that in case the attacker has fired upon the vessel or directed weapons upon the vessel, and provided that the vessel cannot evade the attack, the minimum use of (lethal) force is allowed in order to stop the attack, with an additional clarification that the use of (lethal) force is allowed to escalate in case of a continued attack, until the attack is broken off.

\subsection{Open Issues}

\subsubsection{Present and Imminent Attack}

Clause 6(a)(iii) GUARDCON refers to "monitoring suspicious vessels or craft during the Transit" as one of the main Contractors' duties. It is, however, unclear to what extent a suspicious vessel constitutes a threat that would justify a series of measures to be undertaken, including possible use of force. Under what circumstances are the Contractors expected to conclude that a suspicious vessel represents a clear possibility of an imminent attack, and under what circumstances is such a vessel to be considered to constitute a clear possibility of a present attack? In addition, does an approach of a suspicious vessel constitute the necessary elements required for legitimate use of lethal force?

In a recently reported case occurring in the Straits of Hormuz, after a sighting of a high-speed skiff approaching the tanker, the Master of Vessel decided to take a series of evasive measures as preemptive action. When the skiff approached the tanker, the crew sighted three armed persons equipped with boarding hooks and ropes. The tanker continued with the nonlethal evasive measures and successfully thwarted the attack. ${ }^{67}$ This is a good example of how nonlethal and nonforceful measures can successfully be utilized to thwart a clearly imminent attack. Thus, and as many previously examined guidelines suggest, the (lethal) force should only be used when the attack is imminent and when no other means are available to prevent the occurrence of the attack. From the few available undisputed facts in connection to the Enrica Lexie case, it is difficult to ascertain whether the Team Leader made

\footnotetext{
${ }^{66} \mathrm{~A}$ detailed description of the available means, with or without the presence of non-armed or armed guards on the vessels, is available in: Industry Stakeholders (2011). The document was endorsed by the IMO, and published as: IMO (2011).

${ }^{67}$ Aburgus Risk Management, October 2014c.
} 
any sort of suggestions to the Master of Vessel with regard the use of other means prior to resorting to deadly force.

\subsubsection{Reasonability and Proportionality vs. Extreme Circumstances}

A pirate skiff may follow the vessel and scout the premises. Is the use of lethal force necessary in order to protect the vessel under such circumstances? In addition, what constitutes a reasonable measure as opposed to unreasonable measures? Is the rule of proportionality a guiding principle to be used for all circumstances, or can the existence of extreme circumstances (such as the occasion of exchange of fire, including heavy weaponry) negate the rule of proportionality and exempt the actor from liability?

In accordance with the report of the International Chamber of Commerce's (ICC's) International Maritime Bureau with regard to the attack on the bulk carrier Golden Ice, which occurred on 9 December $2013,{ }^{68}$ following an armed attack of a pirate skiff, ${ }^{69}$ the Master of Vessel undertook a series of actions in accordance with the Best Management Practices (BMP, consisting of the following activities: alarm, fire hoses activated, evasive maneuvers, and, finally, the crew's retreat to the protection of citadel).$^{70}$ Irrespective of the fact that the armed security guards had made their presence visible,$^{71}$ the pirates continued with the aggression. Following a warning flare (general discharge of weapons) and a warning shot (discharge of weapons in the vicinity of the pirate skiff), ${ }^{72}$ the pirates nevertheless pursued the attack and reengaged the vessel with weapons' fire. Finally, the armed security guards engaged the pirates directly, resulting in the pirate's withdrawal. Similarly, in a recent incident that occurred in the Gulf of Oman, two skiffs approached a vessel at full speed, with visible ladders on board the skiffs. The pirates opened fire on the vessel, and the Contractors responded, resulting in the withdrawal of attackers. ${ }^{73}$ Such examples indicate circumstances under which the Contractors are ready (and able) to determine that the use of (lethal) force is the only available means to thwart the attack.

A pirate skiff may attempt to board the vessel by the use of boarding ladders, supported by the use of guns. Is the use of lethal force unavoidable under such circumstances? Is a professional maritime security service provider expected to use proportional measures to thwart the attack without resorting to ultimate deadly force?

\footnotetext{
${ }^{68}$ ICC International Maritime Bureau (2013), p. 25.

${ }^{69}$ Weapons were sighted. For an example where boarding ladders where sighted, sufficing as a proof of hostile intentions, see the report on an attack on a chemical tanker, available in: ICC International Maritime Bureau (2014), p. 28.

${ }^{70}$ Industry Stakeholders (2011).

${ }^{71}$ For examples where this proved to be a sufficient deterrence, see: ICC International Maritime Bureau (2014) - the "Gulf Pearl" case.

${ }^{72}$ For examples where the warning shots have proved to be sufficient, see: ICC International Maritime Bureau (2014)— the "MSC Jasmine" case, "Alba Star" case and "Island Splendor" case.

${ }^{73}$ Aburgus Risk Management (2014b), Issue 29.
} 
In July 2014 in Nigeria, a group of armed pirates attacked an oil rig platform, and a firefight ensued between the attackers and policemen guarding the rig, resulting in the death of five attackers. ${ }^{74}$ In the attack on the tanker SP Brussels, several people (both pirates and crew) lost their lives, following a firefight between armed guards and pirates and the subsequent withdrawal of armed guards and most of the crew to the safety of the citadel. ${ }^{75}$ These cases, as is unfortunately very often the case in some pirate-infested regions such as the West Africa theater of operations, indicate that sometimes the use of force will likely represent the first and, simultaneously, the last means of ensuring security on board a vessel. A stringent rule, stipulating the necessity of following each and every step in accordance with the gradual increase of force severity, may very well hinder or disable the Contractor's ability to provide a successful protection service.

\subsubsection{Conclusion}

It is unlikely that any new set of recommendations and guidelines will offer a critically different approach toward the use of force by private entities engaged in providing private (maritime) security services. A written rule can only provide so much - the rest is left to the professional service providers, consumers, third party interests, and, finally, tribunals. The Nisour Square incident adjudication and the upcoming decision by the Indian Supreme Court (or arbitration decision) in the Enrica Lexie case have and certainly will shed more light on the overall accountability and liability of private military and (maritime) security companies. They have and will provide legal precedents and bases for possible further adjudication and will produce a significant impact on the industry. It is, nevertheless, quite likely that a number of such cases will remain at an all-time low due to the fact that the facts and circumstances surrounding occurrences when the force is utilized by private security providers, devoid of objective, neutral, and third-party oversight and control authority, very often remain blurred and one-sided, making it almost impossible to claim otherwise.

\section{References}

\section{Journals and Articles}

Bueger C (2015) What is maritime security? Mar Policy 53:159-164

Cheadle SP (2009) Private military contractor liability under the worldwide personal protective service II contract. Public Contract Law J 38(3):689-707

\footnotetext{
${ }^{74}$ Aburgus Risk Management (2014a), Issue 28.

${ }^{75}$ See: Gallagher (2014).
} 
Coito JC (2013) Pirates vs. private security: commercial shipping, the Montreux document, and the battle for the Gulf of Aden. Calif Law Rev 101(1):173-226

Dutton YM (2013) Gunslingers on the high seas: a call for regulation. Duke J Comp Int Law 24:107-160

Eboli V, Pierini JP (2012) The 'Enrica Lexie' case and the limits of the extraterritorial jurisdiction of India. I quaderni europei 39:2-27

Gandhi M (2013) The Enrica Lexie Incident: seeing beyond the grey areas of international law. Indian J Int Law 53:1-26

Neri K (2012) The use of force by military vessel protection detachments. Military Law Law War Rev 51(73):74-93

Mudrić M (2011) Armed guards on vessels: insurance and liability. Poredbeno pomorsko pravo 50 (165):217-268

Mudrić M (2015a) The Guardcon contract, knock-for-knock clauses, DCFR and unfair terms (Part I). JIML 21(1):51-62

Mudrić M (2015b) The Guardcon contract, knock-for-knock clauses, DCFR and unfair terms (Part I). JIML 21(2):115-132

Patrick S (2014) Mahard Blackwater's New Battlefield: toward a regulatory regime in the United States for privately armed contractors operating at sea. Vand J Transnatl Law 47:331-369

Petrig A (2013) The use of force and firearms by private maritime security companies against suspected pirates. Int Comp Law Q 62(3):667-701

Scheimer M (2009) Separating private military companies from illegal mercenaries in international law: proposing an international convention for legitimate military and security support the reflects customary international law. Am Univ Int Law Rev 24(3):609-646

Symmons CR (2012) Embarking vessel protection detachments and private armed guards on board commercial vessels: international legal consequences and problems under the law of the sea. Military Law Law War Rev 51:21-53

Tarzwell A (2009) In search of accountability: attributing the conduct of private security contractors to the united states under the doctrine of state responsibility. Oregon Rev Int Law 11:179-204

Tondini M (2012) Some legal and non-legal reflections on the use of armed protection teams on board merchant vessels: an introduction to the topic. Military Law Law War Rev 51(1):7-20

\section{Books and Chapters}

Andreone G, Bevilacqua G, Cataldi G, Cinelli C (2013) Insecurity at sea: piracy and other risks to navigation. Giannini Editore, Napoli

von Bar C, Clive EM (eds) (2010) Principles, definitions and model rules of European private law: draft common frame of reference. Oxford University Press, Oxford

Berube C, Cullen P (eds) (2012) Maritime private security: market responses to piracy, terrorism and waterborne security risks in the 21 st century. Routledge, London

Buckland BS, Burdzy A (2013) Progress and opportunities, five years on: challenges and recommendations for Montreux document endorsing states. DCAF: A Centre for Security, Development and the Rule of Law, Geneva

Chesterman S, Lehnardt C (2007) From mercenaries to market: the rise and regulation of private military companies. Oxford University Press, Oxford

Guilfoyle D (2013) Modern piracy: legal challenges and responses. Edward Elgar, London

Jäger T, Kümmel G (2007) Private military security companies: chances, problems, pitfalls and prospects. VS Verlag für Sozialwissenschaften, Wiesbaden

Kraska J (2011) Contemporary maritime piracy: international law, strategy, and diplomacy at sea. Praeger, Santa Barbara 
Kraska J, Pedrozo R (2013) International maritime security law. Martiuns Nijhoff, Leiden Mejia MQ, Kojima C, Sawyer M (2013) Piracy at sea. Springer, Heidelberg

Mikac R (2013) Suvremena sigurnost i privatne sigurnosne kompanije: Privatizacija sigurnosti i posljedice. Jesenki i Turk, Zagreb

Murdoch A (2011) Recent legal issues and problems relating to acts of piracy off Somalia. In: Symmons CR (ed) Selected contemporary issues in the law of the sea. Nijhoff, The Hague

Murphy J, Witting C (2012) Street on torts. Oxford University Press, Oxford

Percy S (2006) Regulating the private security industry. Routledge, London

Petrig A, Gei $\beta$ R (2011) Piracy and armed robbery at sea: the legal framework for counter-piracy operations in Somalia and the Gulf of Aden. Oxford University Press, Oxford

Prince E (2013) Civilian warriors: the inside story of blackwater and the unsung heroes of the war on terror. Penguin Publishing Group, New York

Tonkin H (2011) State control over private military and security companies in armed conflict. Cambridge University Press, Cambridge

Williams SO (2014) Assessing state jurisdiction and industry regulation over private maritime security: an international and comparative regulatory review. The Artic University of Norway, Narvik

\section{Cases}

Cross v. Kirkby (2000) Times, $5^{\text {th }}$ April (CA)

Darshan Singh v. State of Punjab \& another, Criminal Appeal No. 1057 of 2002

Palmer v. R [1971] AC 814

The "Enrica Lexie" Incident (Italy v. India) Case No. 24, International Tribunal for the Law of the Sea

The "Enrica Lexie" Incident (Italy v. India), International Tribunal for the Law of the Sea Order 24 of August 2015, International Tribunal for the Law of the SeaThe M/V "SAIGA" (No. 2) Case (Saint Vincent and the Grenadines v. Guinea), Case No. 2, International Tribunal for the Law of Sea, ITLOS Rep. 10, § 155United States v. Slough, Criminal No. 2008-0360 (D.C. 2014), District Court, District of Columbia, Filed: May 23rd, 2014

\section{Legal Documents}

Pravilnik o uvjetima koje moraju ispunjavati pravne osobe koje pružaju usluge ukrcaja osoba za naoružanu pratnju na brodove hrvatske državne pripadnosti, Narodne novine, broj 123/12

Regulation on the employment of contractors on board Italian flagged ships sailing in international waters under piracy risk, 29th March 2013, Italian Official Gazette

Title 33 - Navigation and Navigable Waters, Chapter 6 - General Duties of Ship Officers and Owners after Collision or other Accidents, 33 U.S.C. $\$ 383$ - Resistance of pirates by merchant vessels

UK Department for Transport, Interim Guidance to UK Flagged Shipping on the Use of Armed Guards to Defend Against the Threat of Piracy in Exceptional Circumstances, Version 1.2, Updated May 2013

U.S. Department of Homeland Security, United States Coast Guard, Port Security Advisory (3-09), Guidance on Self-Defense or Defense of Others by U.S. Flagged Commercial Vessels Operating in High Risk Waters 


\section{Other}

Gallagher AJ (2014) Marine Market Report: Marine Hull \& Machinery and War Risks Market Update - September 2014. http://www.ajginternational.com/media/95376/ajg-marine-marketreport_sept-2014.pdf. Accessed 1 Dec 2015

Aburgus Risk Management (2014a) Piracy Situation Risk Assessment, August 2014. Issue 28. http://www.aburgus.com/wp-content/uploads/2014/08/Risk-Assessment-August14.pdf. Accessed 1 Dec 2015

Aburgus Risk Management (2014b) Piracy Situation Risk Assessment, September 2014. Issue 29, http://www.aburgus.com/wp-content/uploads/2014/09/Risk-Assessment-Sep-14.pdf. Accessed 1 Dec 2015

Aburgus Risk Management (2014c) Piracy Situation Risk Assessment, October 2014. Issue 30, http://www.aburgus.com/wp-content/uploads/2014/10/Risk-Assessment-Oct-14.pdf. Accessed 1 Dec 2015

American National Standards Institute, Inc. ASIS International (2013) Quality Assurance and Security Management for Private Security Companies Operating at Sea - Guidance ANSI/ ASIS PSC.4-2013

BIMCO (2012a) GUARDCON Standard Contract for the Employment of Security Guards on Vessels (2012)

BIMCO (2012b) Guidance on Rules for the Use of Force (RUF) by Privately Contracted Armed Security Personnel (PCASP) in Defence of a Merchant Vessel (MV)

Globus Intelligence Ltd (2013) The 100 Series Rules: An International Model Set of Maritime Rules for the Use of Force (RUF)

Hindu, December 16, 2014. http://www.thehindu.com/news/resources/timeline-the-italianmarines-case/article4538162.ece. Accessed 1 Dec 2015

Indian Ministry of Shipping (2011) Guidelines on Deployment of Armed Security Guards on Merchant Ships. F.No. SR-13020/6/2009-MG(pt.)

Industry Stakeholders (2011) BMP4 - Best Management Practices for Protection against Somalia Based Piracy, Suggested Planning and Operational Practices for Ship Operators and Masters of Ships Transiting the High Risk Area. Version 4

International Association of Maritime Security Professionals (2011) Use of Force. IAMSP-201101-UOF-001 v2.0

International Chamber of Commerce, International Maritime Bureau (2013) Piracy and Armed Robbery against Ships: Report for the Period 1 January - 31 December 2013

International Chamber of Commerce, International Maritime Bureau (2014) Piracy and Armed Robbery against Ships: Report for the Period 1 January - 31 December 2014

International Committee of the Red Cross (2009) The Montreux Document: On pertinent international legal obligations and good practices for States related to operations of private military and security companies during armed conflict. Swiss Confederation Federal Department of Foreign Affairs, Geneva

International Maritime Organization (2012a) Interim Guidance to private maritime security companies providing contracted armed security personnel on board ships in the High Risk Area. MSC.1/Circ. 1443

International Maritime Organization (2011) Piracy and Armed Robbery against Ships in Waters off Somalia, Best Management Practices for Protection against Somalia Based Piracy. MSC.1/ Circ. 1339

International Maritime Organization (2012b), Revised Interim Guidance to Shipowners, Ship Operators and Shipmasters on the Use of Privately Contracted Armed Security Personnel on board Ships in the High Risk Area. MSC.1/Circ.1405/Rev.2

International Organization for Standardization (2012) The ISO/PAS 28007:2012 Ships and marine technology - Guidelines for Private Maritime Security Companies (PMSC) providing privately contracted armed security personnel (PCASP) on board ships (and pro forma contract) 
International Tribunal for the Law of the Sea (2015) The "Enrica Lexie" Incident (Italy v. India), Provisional Measures. ITLOS/Press 237

Katz A (2012) Fighting Piracy Goes Awry with Killings of Fishermen. Bloomberg Business, September 17

Los Angeles Times, October 22, 2014. http://www.latimes.com/nation/la-na-iraq-blackwater-ver dict-20140903-story.html?track=rss\#page $=1$. Accessed 1 Dec 2015

Maritime Security Centre - Horn of Africa (MSCHOA). http://www.mschoa.org/on-shore/home. Accessed 1 Dec 2015

Den Norske Krigsforsikring for Skib - Gjensidig Forening (The Norwegian Shipowners' Mutual War Risks Insurance Association) (2011) Guidance on the Selection of Private Security Companies (PSC)

Norwegian Mar. Directorate (2011) Provisional Guidelines - Use of Armed Guards on Board Norwegian Ships

Reuters, 10 June 2013, Murder trial of Italian marines in India navigates murky waters

U.S. Department of State (2006) Foreign Operations and Related Programs Appropriations for Fiscal Year 2006: Hearings before a Subcommittee of the Committee on Appropriations. U.S. Senate, Mission Firearms Policy: American Embassy - Baghdad

U.S. Department of State (2009) Private Security Contracting in Iraq and Afghanistan: Statement of Ambassador Richard J. Griffin

Open Access This chapter is licensed under the terms of the Creative Commons AttributionNonCommercial 4.0 International License (http://creativecommons.org/licenses/by-nc/4.0/), which permits any noncommercial use, sharing, adaptation, distribution and reproduction in any medium or format, as long as you give appropriate credit to the original author(s) and the source, provide a link to the Creative Commons license and indicate if changes were made.

The images or other third party material in this chapter are included in the chapter's Creative Commons license, unless indicated otherwise in a credit line to the material. If material is not included in the chapter's Creative Commons license and your intended use is not permitted by statutory regulation or exceeds the permitted use, you will need to obtain permission directly from the copyright holder. 